\title{
MODEL INTERNALISASI NILAI-NILAI ISLAMI DALAM KEHIDUPAN SISWA-SISWI SMP PEMUDA GARUT
}

\author{
Dedih Surana \\ Program Studi Pendidikan Agama Islam, Fakultas Tarbiyah dan Keguruan Unisba \\ Jl. Ranggagading No. 8, 40116, Bandung, Indonesia \\ Email: dedihsurana@gmail.com \\ DOI: $10.29313 /$ tjpi.v6i1.2372 \\ Accepted: April 11th, 2017. Approved: July 20th, 2017. Published: July 20th, 2017
}

\begin{abstract}
$V$ arious social issues of concern in the form of behavior are not commendable is sweeping the nation today. Education world faces severe challenges and must immediately improve itself. SMP Pemuda Garut this challenge with program internalization of Islamic values in the life of students every day. Model internalization is realized by the program: 1) tadarus Qur'an; 2) habituation Dzubur prayer in congregation; 3) habituation Duba prayer; 4) tabfizd Juz. Amma and letters are elected; 5) habituation well-behaved, polite, and Islamic. Guidance is designed in four parts: 1) objectives, 2) program, 3) the implementation process, and 4) evaluation. With the process of internalization through ways: 1) teaching, 2) habituation, 3) imitation, 4) motivating, and 5) the enforcement of the rules.
\end{abstract}

Keywords: Model Internalization, and Islamic values.

\section{ABSTRAK}

Beragam persoalan sosial yang memprihatinkan dalam bentuk berbagai perilaku tidak terpuji sedang melanda anak bangsa saat ini. Dunia pendidikan menghadapi tantangan berat dan harus segera berbenah diri. SMP Pemuda Garut menjawab tantangan ini dengan program internalisasi nilai-nilai Islami dalam kehidupan siswa-siswi sehari-hari. Model internalisasi diwujudkan dengan program: 1) tadarus al-Qur'an: 2) pembiasaan Shalat Dzubur berjamaah; 3) pembiasaan Shalat Duba; 4) tahfizd Juz. Amma dan Surat-surat terpilib; 5) pembiasaan berperilaku baik, sopan, dan Islami. Pembinaan dirancang dalam empat komponen, yaitu: 1) tujuan, 2) program, 3) proses implementasi, dan 4) evaluasi. Dengan proses internalisasi melalui cara: 1) pengajaran, 2) pembiasaan, 3) peneladanan, 4) pemotivasian, dan 5) penegakan aturan.

Kata Kunci: Model Internalisasi, dan Nilai-nilai Islami. 


\section{PENDAHULUAN}

Dewasa ini terdapat beragam fenomena perilaku anak bangsa yang tidak terpuji dan tidak sesuai dengan nilai-nilai luhur budaya dan karakter bangsa, juga tidak bersesuaian dengan ajaran Islam. Dekadensi moral, perkelahian pelajar, perilaku menyimpang di kalangan remaja sudah sedemikian maraknya. Fenomena sosial yang memprihatinkan akhir-akhir ini muncul dalam bebagai bentuk kasus kekerasan dan kerusuhan di Indonesia. Beberapa studi memperlihatkan adanya peningkatan kasus kekerasan dan kerusuhan secara signifikan, baik kuantitas jumlah kasus maupun kualitas intensitasnya.

Pada sisi lain, saat ideologi globalisasi mengalir deras ke semua dimensi kehidupan pada saat itu pula terjadi proses alienasi nilainilai budaya dan kearifan masyarakat lokal yang mengakibatkan kegamangan nilai. Kegamangan ini muncul karena kecenderungan manusia era global lebih mengutamakan akal dan memarginalkan peranan nilai-nilai ilabiyah ajaran agama. Akibatnya, manusia kehilangan ruh kemanusiaan yang hampa dari nilai-nilai spiritual. Kemampuan daya nalar telah mencapai puncaknya yang tidak dibarengi dengan kekuatan ruhaniah, berakibat hidup menjadi kosong makna.

Akibat dari kondisi tersebut, kini sumber-sumber nilai yang menjadi panutan sangat beragam. Keluarga dan lingungan sosial yang semula menjadi sumber nilai dominan mengalami reduksi peran. Institusi pendidikan, institusi pekerjaan, media informasi dan persentuhan dengan budaya lain merupakan penganekaragaman sumber nilai yang menjadi rujukan bagi masyarakat. Sehingga proses enkulturasi seperti imitasi dapat dilakukan melalui media-media lain yang amat dipengaruhi nilai-nilai global.

Dalam kondisi semacam itu, ada kecenderungan pertahanan nilai moral yang menjadi pegangan masyarakat akan semakin tergoyahkan. Nilai tradisi bangsa Indonesia yang ramah, lembut, santun dan religius bisa tergilas oleh nilai-nilai baru yang berstandar pada kebebasan dengan mengatasnamakan hak asasi. Sehingga standar nilai yang dipegang oleh masyarakat akan semakin tidak jelas dan mudah digantikan dengan standar lainnya. Nilai-nilai yang bersumber kepada budaya dan tatanan nilai masyarakat akan mengalami perubahan dari waktu ke waktu. Karena itu, rujukan nilai moral yang dikembangkan oleh pendidikan tidak cukup hanya berdasarkan kepada nilai moral masyarakat, melinkan nilai transcendental yang bersumber dari ajaran agama.

Menyikapi kondisi dan fonomena yang demikian, lembaga pendidikan hendaknya mampu menjawab tantangan dan arus perkembangan zaman ini. Poin penting dari tugas pendidikan adalah membangun karakter anak didik. Menyikapi tantangan feomena sosial tersebut, dan sebagai upaya membentuk karakter peserta didik yang Islami, SMP Pemuda Garut, melaksanakan program penanaman nilai-nilai Islami dalam kehidupan siswa-siswi sehari-hari.

Program internalisasi nilai di SMP Pemuda ini didorong oleh kenyataan bahwa penyelenggaraan pendidikan selama ini masih memiliki beberapa kelemahan, di antaranya: (1) pendidikan belum mampu mengembangkan potensi anak didik secara optimal, terutama dalam pengembangan fitrah beragama; (2) pendidikan belum mampu menyelenggarakan pembelajaran yang aktif, inovatif, kreatif, menyenangkan; (3) pendidikan belum mampu mewujudkan pendidikan yang integratif mengembangkan kecerdasan intelektual, emosional, dan spiritual secara seimbang; (4) pendidikan belum mampu menghasilkan lulusan yang memiliki integritas moral; dan (5) penyelenggaraan pendidikan selama ini masih bersifat dikhotomi, pemisahan antara ilmu agama dan ilmu umum, sehingga menghasilkan lulusan yang cerdas secara farsial, tidak utuh dan paripurna.

Bagaimana model internalisasi nilainilai Islami dalam kehidupan siswa-siswi SMP Pemuda Garut? Apa dan bagaimana tujuannya? Apa program-programnya? Bagaimana Proses internalisasi dilakukan? 
Bagaimana program internalisasi dievaluasi? dan bagaimana hasinya? Itulah beberapa pertanyaan kunci yang hendak dibahas dalam penelitian ini.

\section{METODOLOGI PENELITIAN}

Pendekatan dalam penelitian ini adalah kualitatif, dengan metode deskriptif. Teknik pengumpulan data dilakukan melalui teknik observasi, wawancara, dokumentasi, dan studi literatur. Pengolahan data dilakukan dengan menggunakan langkahlangkah sebagai berikut: Pertama, koleksi data (data collection) yaitu mengumpulkan data melalui observasi dan wawancara yang mendalam serta dokumentasi. Untuk hal tersebut penulis menggunakan catatan lapangan dan pedoman wawancara yang telah disusun. Kedua, mereduksi data (data reduction) yaitu mencatat atau mengetik kembali dalam bentuk uraian atau laporan terinci. Laporan lapangan yang direduksi, dirangkum, dipilih hal-hal yang pokok, diberi susunan yang lebih sistematis supaya mudah dikendalikan. Ketiga, mendisplay data (data display) yaitu upaya untuk melihat gambaran secara keseluruhan atau bagianbagian tertentu dari data penelitian. Untuk itu dibuat dalam berbagai matriks, grafik dan chart. Keempat, menverifikasi data ( data verification) yaitu upaya mencari makna data yang dikumpulkan melalui penafsiran dan interpretasi. Pengolahan data dilakukan dengan menginventarisasi dan mengklasifikasi data yang telah terkumpul untuk kemudian dilakukan deskripsi secara objektif dan sistematis.

\section{PEMBAHASAN}

Secara umum nilai dapat dimaknai sebagai hal yang penting atau berguna bagi kemanusiaan. Menurut Gordon Allfort (Rohmat Mulyana, 2011) nilai adalah keyakinan yang membuat seseorang bertindak atas dasar pilihannya. Nilai merupakan rujukan dan keyakinan dalam menentukan pilihan. Hakikat dan makna nilai adalah berupa norma, etika, peraturan, undang-undang, adat kebiasaan, aturan agama dan rujukan lainnya yang memiliki harga dan dirasakan berharga bagi seseorang dalam menjalani kehidupannya. Secara lebih singkat dan sederhana, nilai adalah rujukan dan keyakinan dalam menentukan pilihan.

Pendidikan nilai adalah proses bimbingan melalui suri tauladan pendidikan yang berorientasi pada penanaman nilai-nilai kehidupan yang didalamnya mencakup nilai agama, budaya, etika, dan estetika menuju pembentukan pribadi peserta didik yang memiliki kecerdasan spiritual, pengendalian diri, kepribadian yang utuh, berakhlak mulia, serta keterampilan yang diperlukan dirinya, masyarakat dan negara (Sofyan Saori, dan Ahmad Hufad, 2007). Secara khusus, pendidikan nilai ditujukan untuk: (a) menerapkan pembentukan nilai kepada anak; (b) menghasilkan sikap yang mencerminkan nilai-nilai yang diinginkan; (c) membimbing perilaku yang konsisten dengan nilai-nilai tersebut. Dengan demikian tujuan pendidikan nilai meliputi tindakan mendidik yang berlangsung mulai dari usaha penyadaran nilai sampai pada perwujudan perilaku-perilaku yang bernilai.

Pendidikan nilai erat kaitannya dengan pendidikan karakter, hal ini mengingat bahwa inti pendidikan nilai adalah pendidikan nilai-nilai karakter. Thomas Lickona (2013) mendefisikan pendidikan karakter: Character education is the deliberate effort to help people understand, care about, and act upon core ethical values. Bahwa pendidikan karakter adalah upaya yang disengaja untuk membantu orang memahami, peduli, dan bertindak berdasarkan nilai-nilai etika inti.

Sementara Anne D. Maatter \& Louis B Weldon (2006) merumuskan: Character education is the deliberate effort to help people understand, care about, and act upon core ethical values. When we think about the kind of character we want for our children, it is clear that we want them to be able to judge what is right, care deeply abaout what is right, and then do what they believe to be right, even in the face of pressure from without 
and temptation from within. Berdasar pandangan ini dapat dipahami bahwa pendidikan karakter adalah upaya yang disengaja untuk membantu orang memahami, peduli, dan bertindak berdasarkan nilai-nilai etika inti. Ketika kita berpikir tentang jenis karakter yang kita inginkan untuk anak-anak kita, jelas bahwa kita ingin mereka untuk dapat menilai apa yang benar, sangat peduli tentang apa yang benar, dan kemudian melakukan apa yang mereka yakini benar, bahkan mampu menghadapi tekanan dari luar dan godaan dari dalam.

Gagasan inovatif UNESCO meliputi empat pilar pendidikan, yaitu belajar mengetahui (learning to know), belajar berbuat (learning to do), belajar menjadi diri sendiri (learning to be), dan belajar hidup bersama (learning to live together). Apabila empat pilar itu diartikulasikan dalam pembelajaran nilai karakter, maka pendidikan nilai dituntut untuk menyediakan suasana kondusif bagi perkembangan peserta didik, yang dilakukan melalui cara-cara penyadaran nilai.

Pertama, peserta didik perlu dibimbing untuk memperluas wawasan pengetahuannya tentang nilai, sehingga mereka dapat memberikan alasan-alasan moral yang tepat sebelum mereka dituntut melakukannya dalam tindakan. Pendekatan berpikir yang perlu dikembangkan dalam proses pembelajaran nilai adalah pendekatan konstruktivisme, yakni membuka pengalaman, pengetahuan, dan pemahaman secara aktif dengan melibatkan alasan-alasan moral (moral reasoning) siswa. Dengan cara demikian, proses belajar untuk mengetahui (learning to know) terhadap nilai kebenaran, kebaikan, dan keindahan dapat dilakukan secara sukarela, walaupun akhirnya diperlukan penegasan-penegasan dari pihak pendidik.

Kedua, peserta didik perlu dibimbing untuk terampil melakukan suatu tindakan dari apa yang diyakininya sebagai nilai kebenaran, kebaikan, dan keindahan. Tindakan atau perbuatan adalah dua hal yang melekat dalam kehidupan nyata, sehingga pada hakikatnya belajar bertindak dan berbuat merupakan belajar mengalami kehidupan yang sebenarnya. Hal ini berarti bahwa membimbing dan melatih peserta didik untuk belajar bertindak dan berbuat (learning to do) harus dilakukan secara kontekstual sesuai dengan pengalaman hidup yang tengah dialami dan prediksi perilaku di masa mendatang.

Ketiga, peserta didik perlu dibimbing kea rah pemilikan sifat-sifat yang baik secara melekat. Nilai yang diputuskan sebagai kebenaran melalui alasan-alasan moral dan tindakan yang dilakukan dalam pengawasan dan bimbingan guru sebelum menjadi jaminan adanya keberlangsungan yang lama pada diri peserta didik. Untuk itu, proses pendidikan nilai memerlukan konsistensi, intensitas, dan frekuensi dalam membiasakan hal-hal terpuji pada peserta didik, sehingga belajar untuk menjadi dirinya sendiri (learning to be) benar-benar melibatkan proses internalisasi yang mendalam.

Keempat, peserta didik perlu dibimbing untuk hidup secara harmonis dengan lingkungannya. Ia tidak dapat hidup tanpa ada kepentingan dengan orang lain. Sebagai anggota masyarakat ia dituntut untuk mampu menampilkan perilakuperilaku yang baik dan benar sehingga ia dapat hidup bahagia dan tidak merugikan orang lain. Karena itu, proses pebelajaran nilai pada peserta didik selain melibatkan kebebasan memilih, keaslian tindakan, dan konsistensi bimbingan juga membutuhkan adanya keterlibatan dari berbagai pihak keluarga dan masyarakat, untuk ikut memfasilitasi peserta didik agar mereka belajar hidup bersama (learning to live together).

\section{Internalisasi Nilai}

Internalisasi nilai ialah menyatunya nilai dalam diri seseorang, atau dalam bahasa psikologi merupakan penyesuaian keyakinan, nilai, sikap, praktik, dan aturan baku pada diri seseorang (Rohmat Mulyana, 2011: 21). Pengertian ini memberi makna 
bahwa internalisasi adalah proses penyadaran, pemilikan, dan penyatuan nilai dalam diri seseorang. Hal ini berarti bahwa internalisasi nilai adalah bagian penting dari proses pendidikan nilai. Internalisasi nilai sebagai upaya pendidikan nilai-nilai karakter yang bertujuan untuk menanamkan dan mempribadikan nilai-nilai luhur dan mulia pada diri peserta didik.

Hers (Mohamad Ali, (2007) mengemukakan empat model pendidikan moral yaitu: 1) Teknik pengungkapan nilai; 2) Analisis nilai; 3) Pengembangan kognitif moral; dan 4) Tindakan sosial. Pertama, Model pengungkapan nilai adalah teknik yang memandang pendidikan moral dalam pengertian promoting self awareness and self caring dan bukan mengatasi masalah moral yang membantu mengungkapkan moral yang dimiliki peserta didik tentang hal-hal tertentu. Pendekatannya dilakukan dengan cara membantu peserta didik menemukan dan menilai atau menguji nilai yang mereka miliki untuk mencapai perasaan diri. Kedua, Model analisis nilai adalah model yang membantu peserta didik mempelajari pengambilan keputusan melalui proses langkah demi langkah dengan cara yang sangat sistematis. Ketiga, Model pengembangan kognitif moral adalah model yang membantu peserta didik berpikir melalui pertentangan dengan cara yang lebih jelas dan menyeluruh melalui tahapantahapan umum dari pertimbangan moral. Keempat, Model tindakan sosial adalah model yang bertujuan meningkatkan keefektifan peserta didik mengungkap, meneliti, dan memecahkan masalah sosial.

Muhaimin (1996: 153) menjelasan bahwa dalam internalisasi yang dikaitkan dengan tingkah laku siswa terdapat tiga tahapan proses internalisasi. Pertama, Transformasi nilai. Tahap ini merupakan suatu proses yang dilakukan oleh guru dalam menginformasikan nilai-nilai kepada siswa. Pada tahap ini hanya terjadi semata-mata komunikasi verbal antara guru dan siswa. Kedua, Transaksi nilai. Tahap pendidikan nilai dengan jalan melakukan komunikasi dua arah, atau interaksi timbal balik antara siswa dengan guru. Guru tidak hanya menyajikan informasi tentang nilai yang baik dan yang buruk, tetapi juga terlibat untuk melakukan dan memberikan contoh nyata dan siswa diminta memberikan respons yang sama, yaitu menerima dan mengamalkan nilai itu. Ketiga, Transinternalisasi. Tahap ini jauh lebih mendalam dari sekedar tahap transaksi. Dalam tahap ini penampilan guru dihadapan siswa bukan lagi sosok fisiknya, melainkan sikap mental kepribadiannya. Oleh karena itu, dapat dikatakan dalam transinternalisasi ini adalah komunikasi dan kepribadian masing-masing terlibat secara aktif.

\section{Konseptual Model Internalisasi Nilai}

Kerangka konseptual model sangat dibutuhkan dalam internalisasi nilai. Dalam hal ini Aan Hasanah (2013) menawarkan kerangka konseptual model yang berintikan empat basic teaching model. Keempat basic teaching model itu ialah (1) tujuan, (2) program, (3) proses, dan (4) evaluasi.

Penanaman nilai dimulai dengan: Pertama, menentapkan tujuan yang akan mengarahkan seluruh program dan proses pada satu arah yang jelas. Tujuan merupakan kristalisasi nilai-nilai yang berfungsi mengarahkan, sekaligus memberi makna pada program dan proses berikutnya. Kedua, program yang hendak dijalankan mesti mengarah pada tujuan yang hendak dicapai. Program merupakan rancangan yang terencana dan terukur yang sudah ditentukan. Program akan menentukan kualitas ketercapaian pendidikan. Ketiga, Proses yang akan mengimplementasikan program. Proses adalah suatu kegiatan yang mengarahkan dengan sengaja program yang telah dirancang untuk mencapai tujuan yang hendak dicapai. Keempat, Evaluasi untuk mengukur berhasil tidaknya model yang dijalankan. Evaluasi sangat penting dalam proses pendidikan, karena tujuan evaluasi pendidikan bukan hanya untuk mengukur keberhasilan program pendidikan, tetapi 
juga sebagai langkah korektif untuk lebih baik. Konseptual model internalisasi nilai dijabarkan dalam diagram berikut ini:

Gambar 1. Internalisasi Nilai Islami

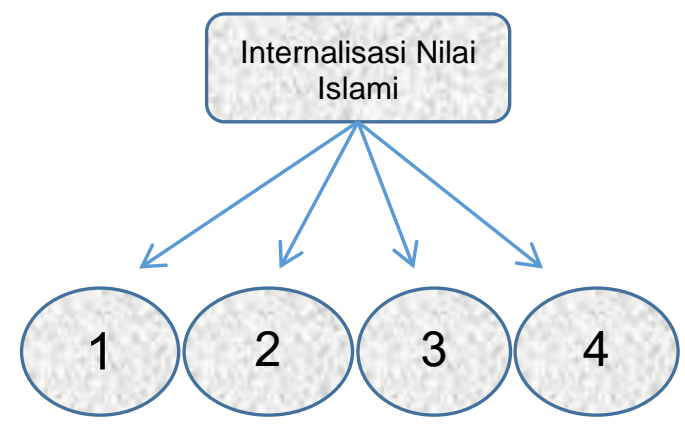

\section{Metode Internalisasi Nilai}

Konseptual model internalisasi nilainilai Islami diimplementasikan melalui metode: (1) pengajaran, (2) pembiasaan, 3) peneladanan, (4) pemotivasian, serta (5) penegakan aturan (Aan Hasanah, 2013). Dalam implementasi di lapangan, metodemetode internalisasi nilai ini dipetakan dalam beberapa program kegiatan dan pembinaan.

Pegajaran. Pendidikan karakter dimulai dengan memberikan pengajaran nilai-nilai Islami kepada anak didik. Memberikan pengajaran kepada anak didik nilai-nilai baik yang harus dimiliki dan nilainilai buruk yang harus dihindari. Perilaku mana yang baik yang harus dilakukan dan perilaku mana yang buruk yang harus dijauhi. Anak didik diberi pengajaran untuk memahami sifat-sifat terpuji yang harus dimiliki dan sifat-sifat tercela yang harus dihindari. Intinya, memberikan pengajaran kepada peserta didik untuk memahami dan mempraktekan nilai-nilai karakter yang baik/terpuji, serta menghindari sifat-sifat dan nilai karakter yang buruk/tercela.

Pengajaran sering didefinisikan sebagai sebuah proses penyampaian informasi atau pengetahuan dari guru atau pendidik kepada siswa atau peserta didik. Mengajarkan nilai-nilai Islami berarti memberikan pemahaman kepada peserta didik tentang struktur, keutamaan dan maslahatnya, tuntunan dan tata caranya. Megajarkan nilai memiliki dua faedah, pertama, memberikan pengetahuan konsep tentang nilai, kedua membandingkan atas pengetahuan yang telah dimiliki oleh peserta didik. Internalisasi nilai-nilai Islami penting didahului dengan pengajaran nilai-nilai Islami kepada peserta didik, agar mereka mengenal, mengetahui, dan memahami nilainilai baik atau buruk, benar atau salah, terpuji atau tercela. Perilaku mana yang seharusnya dilakukan dan perilaku mana yang seharusnya ditinggalkan dalam perspektif Islam.

Pengajaran atau ta'lim dapat dimaknai dengan memberikan pemahaman dan wawasan melalui berbagai ilmu pengetahuan dan informasi dalam rangka mengubah pola pikir (mindset) manusia. Perubahan pola pikir merupakan tugas yang amat penting dan mendasar, karena dalam perubahan pola pikir inilah akan terjadi perubahan sikap dan perilaku. Pengajaran atau ta'lim antara lain dijumpai pada Qs. 2: 31 yang artinya:

Dan Dia mengajarkan kepada Adam nama-nama (benda-benda) selurubnya, kemudian mengemukakannya kepada para malaikat lalu berfirman: "Sebutkanlah kepada-Ku nama bendabenda itu jikea kamu memang orang-orang yang benar!"

Al-Maraghi menafsirkan bahwa ta'lim adalah pengajaran yang dilakukan secara bertahap, sebagaimana tahapan Adam As mempelajari, menyaksikan, dan menganalisa asma-asma yang diajarkan oleh Allah kepadanya. Ini berarti bahwa pengajaran tidak hanya mencakup aspek kognitif belaka, melainkan melibatkan domain lainnya.

Keteladanan. Yaitu pendidikan karakter dengan memberikan uswah hasanah atau contoh teladan yang baik. Anak belajar dari lingkungannya dan dari orang-orang dewasa yang berada di sekitarnya. Sikap imitasi atau meniru sangat menonjol pada usia anak. Perkembangan aspek-aspek psikologis dan kemampuan anak yang lain yang berkembang lewat proses peniruan. 
Pada mulanya anak beragama karena meniru orang tuanya. Salah satu ciri kehidupan beragama pada masa kanak-kanak adalah sifatnya yang imitatif. Anak-anak beragama dengan meniru apa yang diyakini dan dilakukan orang tuan dan orang-orang dewasa disekitarnya.

Keteladanan adalah metode pendidikan nilai yang paling efektif, sebagaimana dicontohkan oleh Rasulullah saw. Dakwah yang dilakukan Rasulullah banyak dilakukan dengan peneladanan. Rasulullah adalah teladan dalam semua aspek kehidupan. Rasulullah sebagai teladan dalam ketaatan dan beribadah kepada Allah. Rasulullah teladan sebagai sosok suami, sebagai pemimpim umat, sebagai pedagang, sebagai prajurit dan komandan perang.

Keteladanan menempati posisi yang sangat penting dalam pendidikan karakter. Anak didik lebih banyak belajar dari apa yang mereka lihat. Oleh karena itu, pendidik harus terlebih dahulu menjadi teladan, dengan memiliki karakter yang hendak diajarkan. Keteladanan tidak hanya bersumber dari pendidik, melainkan juga dari seluruh manusia yang ada di lingkungan pendidikan, termasuk keluarga dan masyarakat. Keteladanan sebagai inti dari pendidikan karakter di lingkungan keluarga, sekolah, dan masyarakat.

Pembiasaan. Dalam pendidikan karakter, pembiasaan memiliki posisi sangat penting sebagai bagian dari proses pembentukan sikap dan perilaku yang relatif menetap dan bersifat otomatis melalui proses pembelajaran yang berulang-ulang. Aan Hasanah (2013) mengemukanan bahwa sikap atau perilaku yang telah menjadi kebiasaan mempunyai cirri: 1) perilaku tersebut reltif menetap. 2) pembiasaan umumnya tidak memerlukan fungsi berpikir tinggi. 3) kebiasaan bukan sebagai hasil dari proses kematangan, tetapi sebagai akibat atau hasil pengalaman atau belajar, 4) kebiasaan tampil berulang-ulang sebagai respon terhadap stimulus yang sama.

Faktor yang mempengaruhi keberhasilan pendidikan karakter adalah adat/kebiasaan. Adat/kebiasaan adalah setiap tindakan dan perbuatan seseorang yang dilakukan secara berulang-ulang dalam bentuk yang sama sehingga menjadi kebiasaan (Zubaedi, 2011: 179).

Pemotivasian. Salah satu hambatan perkembangan anak khususnya dan peserta didik umumnya adalah krisis morivasi. Peserta didik tidak memiliki motivasi yang cukup untuk belajar dan mengembangkan potensi diri, sehingga menghambat pada laju perkembangan dan pengembangan potensi dirinya. Pemotivasian memiliki posisi penting dalam pendidikan karakter. Peserta didik didorong dan dimotivasi untuk memahami nilai-nilai yang baik dan positif bagi dirinya dan berupaya untuk memiliki dan menerapkan nilai-nilai tersebut.

Beberapa bentuk dan cara motivasi antara lain: memberi penghargaan berupa angka, hadiah, kompetisi, member ulangan, mengetahui hasil, pujian, hukuman, hasrat untuk belajar, minat, tujuan yang diakui. Memotivasi berarti juga melibatkan peserta didik dalam proses pendidikan. Mereka diberi kesempatan untuk berkembang secara optimal dan mengeksplorasi seluruh potensi yang dinugrahkan Allah kepadanya.

Penegakan Aturan. Manusia ada kecenderungan melanggar aturan dan norma-norma yang berlaku di masyarakat, salah satunya karena alasan tidak ada penegakan aturan yang baku dan benar. Apabila aturan atau norma sudah tidak ditegakkan dengan benar, manusia akan kehilangan kepercayaan akan kebenaran aturan dan norma tersebut sebagai suatu system nilai yang memberi manfaat bagi kehidupan manusia. Bila demikian adanya, manusia akan mengabaikan dan meninggalkan aturan dan norma tersebut. Sebaliknya, jika aturan dan norma ditegakkan dengan benar ia akan menjadi system nilai yang dihormati dan ditaati setiap orang di komunitasnya. Sehingga lambat laun ia akan menjadi karakter dari perilaku orang-orang di lingkungannya.

Penegakan aturan memiliki peran penting dalam pendidikan karakter. Yaitu 
dengan memberikan kepastian nilai-nilai karakter baik yang perlu dihormati dan dimiliki setiap individu dan nilai-nilai karakter buruk yang harus dijauhi. Penegakan aturan akan memberikan kepastian. Kepastian aturan dan konsekwensinya akan memberikan motivasi kepada setiap warga dari komunitas untuk menegakan nilai-nilai aturan tersebut dan berusaha untuk menerapkan dan menjadi karakter dari tingkah lakunya.

\section{Model Internalisasi Nilai}

Program pembinaan keagamaan atau muatan lokal plus agama Islam SMP Pemuda Garut, merupakan model internalisasi nilai-nilai Islami dalam kehidupan siswa-siswi sehari-hari. Program pembinaan plus agam Islam ini memenuhi standar dan criteria kerangka konseptual model internalisasi nilai, yang setelah diimplementasikan memenuhi criteria sebagai model internalisasi nilai-nilai Islami. $\mathrm{Hal}$ tersebut dapat ditelaah dari empat komponen kerangka konseptual internalisasi nilai, yaitu: 1) Tujuan, 2) Program, 3) Implementasi, dan 4) Evaluasi.

\section{Tujuan Internalisasi Nilai-nilai Islami}

SMP Pemuda Garut memiliki visi: Terdepan dalam prestasi, unggul dalam berkarya, professional dalam bekerja, Religius dan berakblakul karimah. Dengan misi: (1) Mewujudkan prestasi kerja yang profesional; (2) Membangun kerja sama yang efektif dan efesien; (3) Menjadikan sekolah sebagai pusat perkembangan budaya ilmu pegetahuan dan teknologi yang dilandasi nilai agama; (4) Pemberdayaan potensi kependidikan dalam upaya membangun bangsa, negara dan agama.

Tujuan yang ingin dicapai adalah untuk mewujudkan: 1) tercapai standar nasional pendidikan secara bertahap; 2) pendidikan bermutu dan Islami; 3) Memiliki sarana dan prasarana yang memadai; 4) Memiliki lngkungan sekolah yang kondusif bagi pembelajaran; 5) Meningkatkan kegiatan keagamaan dan budaya Islami di sekolah. 6) Terbentuknya organisasi tata pamong sekolah yang baik.

Kurikulum menggunakan kurikulum standar nasional dan muatan lokal berupa plus agama Islam. Muatan Plus agama Islam sebagai bekal bagi siswa-siswi untuk lebih memahami, menghayati dan mengamalan nilai-nilai ajaran Islam dalam kehidupan, serta mampu mewarnai semua aspek hidup sehari-hari dengan nilai-nilai Islami. Secara lebih spesifik muatan lokal plus agama Islam bertujuan agar siswa: (1) memahami ajaran Islam sesuai dengan tahap perkembangan remaja awal. (2) dapat mengamalkan ajaran Islam sebagai seorang muslim dalam kehidupan sehari-hari. (3) mampu baca tuis al-Quran dengan baik dan benar. (4) dapat menampilan perilaku baik, santun, dan Islami, baik dalam hal bertutur kata, berpakaian, dan bergaul atau berinteraksi dengan orang lain.

Tujuan internalisasi nilai-nilai Islami dalam kehidupan sehari-hari siswa-siswi SMP Pemuda Garut, sudah tergambar jelas sejak rumusan visi, misi, dan tujuan sekolah, serta dikuatkan dengan tujuan khusus program plus agama Islam sebagai upaya internalisasi nilai-nilai Islami. Pada visi ditegaskan dengan rumusan: Terdepan dalam prestasi, unggul daam berkarya, professional dalam bekerja, Religius dan berakblakul karimah. Rumusan religius dan berakhlakul karimah memberi visi yang jelas arah pengembangan sekolah dengan muatan nilai-nilai Islam. Demikian pula dengan salah satu misi yang menandaskan: Menjadikan sekolah sebagai pusat perkembangan budaya ilmu pegetabuan dan teknologi yang dilandasi nilai agama bagi masyarakat sekitarnya. Serta tujuan sekolah yang salah satunya untuk mewujudkan pendidikan bermutu dan Islami.

Arah tujuan internalisasi nilai-nilai Islami semakin jelas dan terarah pada rumusan tujuan program Plus agama Islam sebagai upaya internalisasi nilai-nilai Islami dalam kehidupan siswa-siswi SMP Pemuda Garut. Dengan Tujuan: 1) Para siswa 
memahami ajaran Islam sesuai dengan tahap perkembangan remaja awal; 2) Para siswa dapat mengamalkan ajaran Islam sebagai seorang muslim dalam peri kehidupan sehari-hari; 3) Para siswa mampu baca tuis al-Quran dengan baik dan benar; 4) Para siswa mampu membiasakan diri menunaikan shalat dzuhur berjamaah, dan shalat sunat Duha; dan 5) Para siswa mampu menampilan perilaku baik, santun, dan Islami, baik dalam hal bertutur kata, berpakaian, dan bergaul atau berinteraksi dengan orang lain.

Rumusan tujuan tersebut sudah sangat jelas dan gamblang terarah pada pendidikan yang bermutu dan Islami. Tujuan-tujuan ini diharapkan akan mengarahkan seluruh program dan proses internalissasi niai-nilai Islami dalam kehidupan siswa-siswi SMP Pemuda Garut pada satu arah yang jelas. Juga berfungsi mengarahkan, sekaligus memberi makna pada program dan proses berikutnya.

\section{Program Internalisasi Nilai-nilai Islami}

Internalisasi nilai-nilai Islami dalam kehidupan siswa-siswi SMP Pemuda Garut diwujudkan dalam program-program yang jelas, terprogram, dan terarah pada tujuan penanaman nilai-nilai Islami di lingkungan sekolah. Dengan lima program utama, yaitu: 1) Program Tadarus Al-Qur'an; 2) Program Pembiasaan Shalat Dzuhur Berjamaah; 3) Program Pembiasaan Shalat Duha; 4) Program Tahfizd Juz Amma dan Surat-surat terpilih; dan 5) Program Gerakan Berperilaku Baik, Sopan, dan Islami.
Gambar 2. Program Internalisasi Nilai Islami

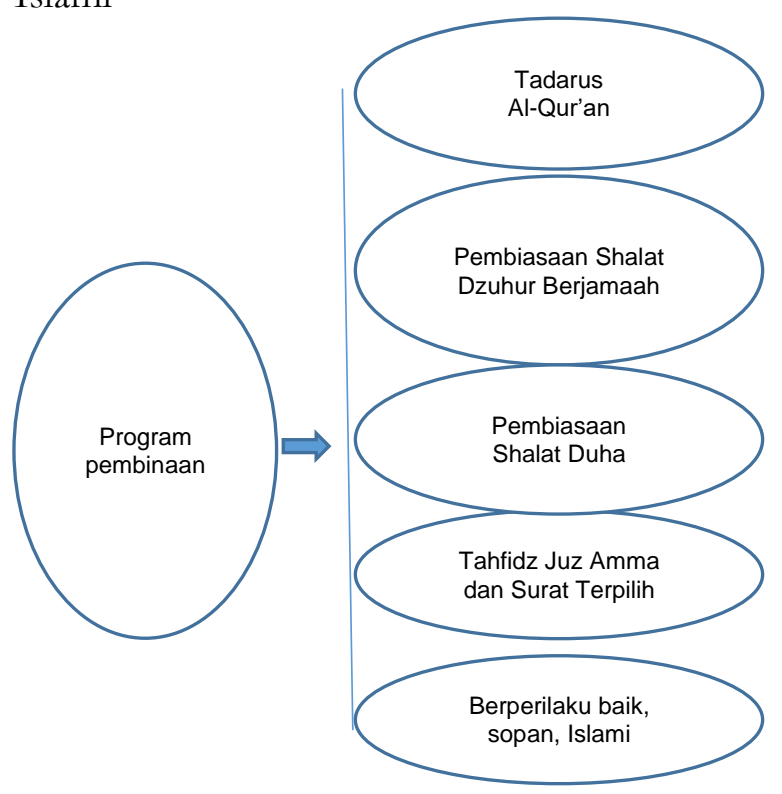

Program Tadarus Al-Qur'an adalah membaca ayat-ayat Al-Qur'an secara berjamaah oleh para siswa yang dilakukan per kelas. Tadarus dilakukan secara rutin setiap mengawali pelajaran, dimulai sejak para siswa masuk di kelas 7 hingga menjelang Ujian Nasional dengan target tiga tahun dapat menamatkan 30 juz Al-Qur'an.

Dengan program tadarus ini diharapkan siswa-siswi terbiasa bergaul dengan al-Quran, terbiasa mendengar dan melafakan ayat-ayat al-Qur'an. Setiap hari para siswa minimal pernah satu kali memegang, membuka, dan membaca alQur'an. Seperti sepele, namun program ini penting bagi pengalaman dan pembiasaan siswa-siswi. Sebagai upaya yang diharapkan dapat memberikan pengaruh positif pada kebiasaan hidup para siswa dan dapat membangkitkan rasa cinta pada Al-Qur'an.

Program shalat Drubur berjamaan dilakukan setiap hari pelajaran. Program shalat Dzuhur berjamaah dilakukan oleh seluruh siswa-siswi dibimbing oleh para guru, khususnya guru Pembina keagamaan SMP Pemuda Garut. Dengan program shalat Dzuhur berjamaah, diharapkan para siswa terbiasa menunaikan shalat fardhu secara berjamaah. Inti program ini adalah upaya pembiasaan bagi siswa-siswi SMP 
Pemuda Garut. Selain itu, para siswa memperoleh praktek langsung menunaikan ibadah fardu berjamaah, dengan bimbingan praktek yang baik dan benar dari para guru.

Program pembiasaan shalat Duba dilakukan setiap hari untuk semua siswasiswi, kecuali yang sedang berhalangan. Dilakukan sebelum memasuki jam pelajaran, yaitu jam 06.50 - 07.00 WIB. Shalat Duha dibimbing oleh guru Pembina keagamaan. Dengan program pembiasaan shalat Duha ini diharapkan para siswa terbiasa menunaikan shalat sunat, minimal shalat sunat Duha, disamping menunaikan kewajiban shalat fardhu. Juga sebagai upaya pembiasaan memulai hari dan aktivitas dengan beribadah kepada Allah, yaitu menunaikan shalat Duha, diiringi doa harapan kepada Allah Ta'ala. Inti program ini adalah pembiasaan. Program ini pula sebagai upaya memberi pengalaman beragama dan upaya mengasah rasa serta kesadaran beragama.

Program Tabfizd Juz. Amma dan surat terpilih dilakukan secara individual dengan system sorogan atau setoran hapalan ayat atau surah kepada ustazd pembimbing. Program tahfizd ini diharapkan akan semakin mendekatkan dan semakin menumbuhkan perasaan mencintai siswasiswi pada al-Qur'an. Disamping itu pula untuk menumbuhkan hasrat memelihara alQur'an dengan cara menghapalnya di kalangan siswa-siswi, serta meningkatkan kebanggaan dan syiar Islam.

Program gerakan berperilaku baik, sopan, dan Islami merupakan penerapan peraturan tata tertib untuk memberikan bimbingan kepada para siswa agar senantiasa mampu berperilaku baik, sopan, dan Islami dalam kehidupan sehari-hari. Juga upaya untuk mencegah para siswa melakukan perbuatan negative atau yang tidak terpuji atau melanggar tata aturan norma yang berlaku dalam masyarakat.

Program ini meliputi penegakan peraturan dalam hal pergaulan, perkataan, cara berpakaian, kedisiplinan, dan kesusilaan. Program ditetapkan melalui surat keputusan bersama yayasan dan kepala sekolah yang berlaku bagi seluruh siswasiswi SMP Pemuda Garut.

Adapun tujuan dari program ini ialah: 1) Menegakan disiplin dan pembinaan akhlak mulia; 2) Membimbing siswa-siswi agar tidak melanggar aturan perundangan dan agar tidak terjerumus pada dekadensi moral; 3) Menegakan nilai-nilai Islam dan budaya Islami, serta membina lingkungan fisik dan sosial yang tertib, disiplin, edukatif, dan Islami.

Kelima program internalisasi nilainilai Islami dalam kehidupan siswa-siswi SMP Pemuda Garut semuanya mengarah dan memperkuat tercapainya tujuan internalisasi nilai-nilai Islami yang dicanangkan. Sebagai program yang terencana dan terukur yang sudah ditentukan yang mengarah pada tujuan yang hendak dicapai, yaitu tertanamnya nilai-nilai Islami dalam kehidupan sehari-hari siswasiswi SMP Pemuda Garut.

\section{Implementasi Internalisasi Nilai-nilai Islami}

Implementasi internalisasi nilai-nilai Islami dalam kehidupan sehari-hari siswasiswi SMP Pemuda Garut adalah bentukbentuk penanaman nilai-nilai Islami melalui lima program utama: 1) Program Tadarus Al-Qur'an; 2) Program Pembiasaan Shalat Dzuhur Berjamaah; 3) Program Pembiasaan Shalat Duha; 4) Program Tahfizd Juz Amma dan Surat-surat terpilih; dan 5) Program Gerakan Berperilaku Baik, Sopan, dan Islami. Kelima program utama ini dalam proses implementasinya dilakukan berdasar urutan proses pendidikan nilai, yaitu: 1) pengajaran, 2) pembiasaan, 3) peneladanan, 4) pemotivasian, serta 5) penegakan aturan.

Pengajaran; Mengajarkan nilai-nilai Islami berarti memberikan pemahaman kepada peserta didik tentang struktur, keutamaan dan maslahatnya, tuntunan dan tata caranya. Megajarkan nilai memiliki dua faedah, pertama, memberikan pengetahuan konsep tentang nilai, kedua membandingkan 
atas pengetahuan yang telah dimiliki oleh peserta didik. Internalisasi nilai-nilai Islami penting didahului dengan pengajaran nilainilai Islami kepada peserta didik, agar mereka mengenal, mengetahui, dan memahami nilai-nalai baik atau buruk, benar atau salah, terpuji atau tercela, perilaku mana yang seharusnya dilakukan dan perilaku mana yang seharusnya ditinggalkan dalam perspektif Islam.

Peneladanan; bahwa keteladanan adalah metode pendidikan nilai yang paling efektif, sebagaimana dicontohkan oleh Rasulullah saw. Dakwah yang dilakukan Rasulullah banyak dilakukan dengan peneladanan. Rasulullah sebagai teladan dalam beribadah dan kedekatan dengan Allah. Rasulullah teladan sebagai sosok suami, sebagai pemimpim umat, sebagai pedagang, sebagai prajurit dan komandan perang, dan sebagai teladan dalam semua aspek kehidupan.

Pembiasaan; metode pembiasaan memiliki posisi sangat penting sebagai bagian dari proses pembentukan sikap dan perilaku yang relative menetap dan bersifat otomatis melalui proses pembelajaran yang berulang-ulang. Factor yang mempengaruhi keberhasilan pendidikan karakter adalah adat/kebiasaan. Adat/kebiasaan adalah setiap tindakan dan perbuatan seseorang yang dilakukan secara berulang-ulang dalam bentuk yang sama sehingga menjadi kebiasaan.

Pemotivasian memiliki posisi penting dalam pendidikan karakter. Peserta didik didorong dan dimotivasi untuk memahami nilai-nilai yang baik dan positif bagi dirinya dan berupaya untuk memiliki dan menerapkan nilai-nilai tersebut. Beberapa bentuk dan cara motivasi antara lain: memberi penghargaan berupa angka, hadiah, kompetisi, member ulangan, mengetahui hasil, pujian, hukuman, hasrat untuk belajar, minat, tujuan yang diakui. Memotivasi berarti juga melibatkan peserta didik dalam proses pendidikan. Mereka diberi kesempatan untuk berkembang secara optimal dan mengeksplorasi seluruh potensi yang dinugrahkan Allah kepadanya.

Penegakan aturan; Penanaman nilai tidak akan berhasil baik bila tidak disertai dengan penegakan aturan. Penegakan aturan memiliki peran penting dalam pendidikan karakter. Yaitu dengan memberikan kepastian nilai-nilai karakter baik yang perlu dihormati dan dimiliki setiap individu dan nilai-nilai karakter buruk yang harus dijauhi. Penegakan aturan akan memberikan kepastian. Kepastian aturan dan konsekwensinya akan memberikan motivasi kepada setiap warga dari komunitas untuk menegakan nilai-nilai aturan tersebut dan berusaha untuk menerapkan dan menjadi karakter dari tingkah lakunya.

Gambar 3. Metode Internalisasi Nilai

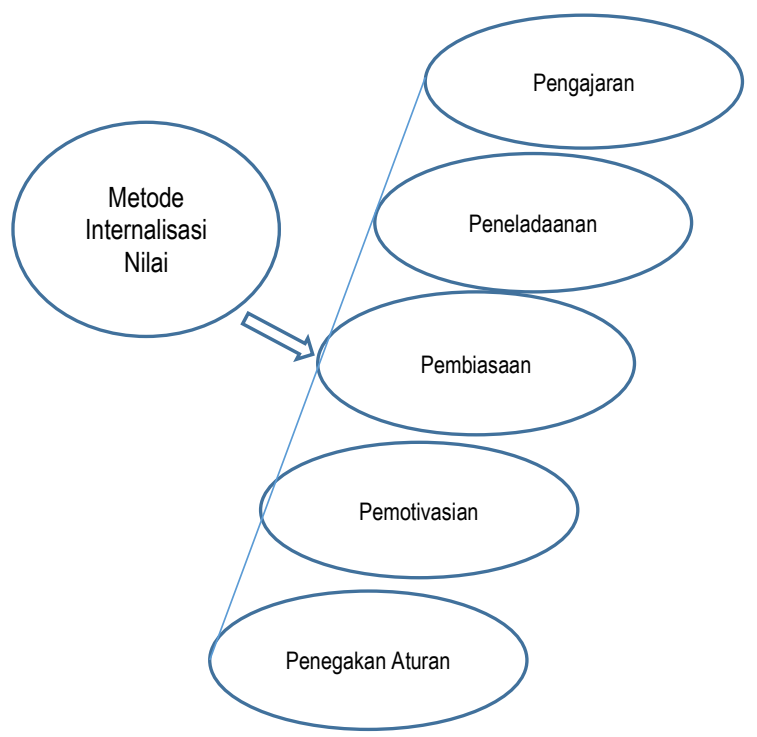

Evaluasi Internalisasi Nilai-nilai Islami

Program-program internalisasi nilai Islami dalam kehidupan siswa-siswi SMP Pemuda Kabupaten Garut dilakukan evaluasi secara berkala. Yaitu evauasi terhadap program tadarus al-Qur'an, pembiasaan Shalat Dhuhur berjamaah, pembiasaan Shalat Sunat Duha, tahfizd Juz Amma dan Surat-surat terpilih, dan program berperilaku baik, sopan, dan Islami. Evaluasi dilakukan untuk mengkaji proses implementasinya, baik berkenaan dengan 
durasi waktu, metode, tingkat keberhasilan atau ketidak berhasilan, pengawasan, faktorfaktor yang berpotensi menjadi hambatan, dan rencana tindak lanjutnya.

Menurut intensitasnya, evaluasi dilakukan per tahun pelajaran, per semester, per tengah semester, dan juga evaluasi harian. Evaluasi tahun pelajaran adalah untuk mengukur keberhasilan, pencapaian, hambatan, potensi pendukung programprogram keagamaan dan penanaman nilainilai Islami selama satu tahun pelajaran. Evaluasi semester atau tengah semester adalah mengukur keberhasilan, pencapaian, hambatan, potensi, dan dukungan programprogram keagamaan pada semester atau tengah semester berjalan.

Hal penting lainnya ialah melakukan evaluasi harian per kegiatan pembelajaran oleh guru atau pembimbing agama. Hal ini penting agar para guru atau pembimbing praktek agama mengetahui, keunggulan, keberhasilan proses pembelajaran yang ia berikan. Juga untuk segera mengetahui kelemahan, kekurangan, hambatan proses pembelajaran yang ia kelola saat itu. Evaluasi dilakukan dengan tes hasil pembelajaran, persepsi para siswa, dan observasi terlibat dalam pembelajaran.

Evaluasi sangat penting dalam proses pendidikan, karena tujuan evaluasi pendidikan bukan hanya untuk mengukur keberhasilan program pendidikan, tetapi juga sebagai langkah korektif untuk lebih baik. Namun demikian, evaluasi dilakukan bukan hanya sekedar formalitas, memenuhi standar proses, melainkan evaluasi bermakna yang memberi bobot bagi kelangsungan dan pencapaian keberhasilan program.

Salah satu moment penting melihat hasil program adalah dalam kegiatan khataman pada tahun ketiga. Pada kegiatan khataman terlihat jelas tingkat keberhasilan program internalisasi nilai-nilai Islami tergambar pada performa dan kompetensi anak didik. Kompetensi anak didik baik dalam aspek kognitif berupa pemahaman ajaran dan hapalan surat-surat Al-Qur'an, aspek afektif sikap dan penghayatan jiwa keagamaan, serta motorik dalam banyak keterampilan dipertontonkan ke khalayak undangan. Dalam moment khataman disamping mengundang penilaian positif orang tua dan tokoh masyarakat, juga mampu menghadirkan suasana hidmat, haru, dan rasa pengalaman beragama yang luar biasa bagi semua yang hadir. Hal ini menguatkan indikator keberhasilan muatan lokal agama Islam dan program penanaman nilai-nilai Islami dalam kehidupan siswasiswi SMP Pemuda Kabupaten Garut.

\section{KESIMPULAN}

Model internalisasi nilai-nilai Islami dalam kehidupan sehari-hari siswa-siswi SMP Pemuda Garut didesain dalam kerangka konseptual model dengan empat komponen utama pendidikan, yaitu: (1) Tujuan internalisasi nilai; (2) Program internalisasi nilai; (3) proses implementasi nilai; dan (4) evaluasi internalisasi nilai. Secara spesifik dapat disimpulkan:

Pertama, Tujuan internalisasi nilainilai Islami dalam kehidupan sehari-hari siswa-siswi SMP Pemuda Garut, sudah tergambar jelas sejak rumusan visi, misi, dan tujuan sekolah, serta dikuatkan dengan tujuan khusus program plus Agama Islam. Tujuan program internalisasi nilai-nilai Islami dalam kehidupan siswa-siswi SMP Pemuda Garut adalah agar para siswa: (1) Memahami ajaran Islam sesuai dengan tahap perkembangan remaja awal; (2) Dapat mengamalkan ajaran Islam sebagai seorang muslim dalam peri kehidupan sehari-hari; (3) Mampu baca tuis al-Quran dengan baik dan benar; (4) Mampu membiasakan diri menunaikan shalat dzuhur berjamaah, dan shalat sunat Duha; (5) Mampu menampilan perilaku baik, santun, dan Islami, baik dalam hal bertutur kata, berpakaian, dan bergaul atau berinteraksi dengan orang lain.

Kedua, internalisasi nilai diwujudkan pada lima program utama: (1) Tadarus AlQur'an; (2) Pembiasaan Shalat Dzuhur Berjamaah; (3) Pembiasaan Shalat Duha; (4). 
Tahfizd Juz Amma dan Surat-surat terpilih; (5) Pembiasaan Berperilaku Baik, Sopan, dan Islami.

Ketiga, Proses internalisasi nilai-nilai Islami dalam kehidupan siswa-siswi SMP Pemuda Garut diimplementasikan dengan lima metode internalisasi nilai, yaitu: (1) melalui proses pengajaran atau pemberian pemahaman, (2) proses pembiasaan, (3) proses peneladanan oleh para guru dan kepala sekolah, (4) pemotivasian, serta (5) penegakan aturan.

Keempat, Evaluasi program-program internalisasi nilai-nilai Islami dalam kehidupan siswa-siswi SMP Pemuda Garut dilakukan dalam bentuk evaluasi harian, tengah semesteran, akhir semester, dan evaluasi program tahunan. Evaluasi dilakukan untuk mengukur berhasil tidaknya model yang dijalankan.

\section{DAFTAR PUSTAKA}

Hasanah, Aan. (2013). Pendidikan Karakter Berperspektif Islam, Bandung: Insan Komunika.

Lickona, Thomas. (2013). Character Matters; Persoalan Karakter Bagaimana Membantu Anak Mengembangkan Penilaian yang Baik, Integritas, dan Kebajikan Penting lainnya, (Terj. Juma Abdu Wamaungo), Jakarta: Bumi Aksara.

Matter, Anne D \& Louis B Weldon. (2006). Character Building Day by Day, Eric Braun: Minneapolis.

Muhaimin. (1996). Strategi Belajar Mengajar, Surabaya, Citra Media.

Mulyana, Rohmat, (2011). Mengartikulasikan Pendidikan Nilai, Bandung: Alfabeta.

Saori, Sofyan, dan Ahmad Hufad. (2007). Pendidikan Nilai, dalam Ali, Mohammad, Ilmu dan Aplikasi Pendidikan, Bandung, Pedagogiana Press.

Zubaedi. (2011). Desain Pendidikan Karakter; Konsepsi dan Aplikasinya dalam Lembaga Pendidikan, Jakarta: Kencana Prenada Media Group. 